\title{
THE ARCHIVE OF TAEMBES, A FEMALE BREWER IN THE HERACLEOPOLITE NOME
}

\begin{abstract}
A group of nine receipts for beer tax from Hibeh in the 3rd century $\mathrm{BC}$ are linked by Taembes, a woman who probably functioned as a tax farmer in Talae (Heracleopolite nome). The receipts were written in double, with a short inner and a full outer text and followed by a subscription in demotic, which has thus far remained unpublished.
\end{abstract}

In 1907 Grenfell and Hunt published nine beer tax receipts from a single mummy case (A 15) found at el-Hibeh. The texts are all written across the fibres, they contain identical formulas, and date from two successive years, years 2 and 3 of an unnamed king, no doubt Ptolemy III. They are double documents, with a short scriptura interior and a full scriptura exterior ${ }^{1}$. At some time the scriptura interior was no doubt sealed, as is clear from the seal hole between upper and lower text ${ }^{2}$. At the end is in each case a Greek signature in a second hand by a certain Dorion and a subscription in demotic ${ }^{3}$.

The monthly payments are made to the logeuterion at Phebichis, the main centre of the Koites toparchy of the Heracleopolite nome ${ }^{4}$ and range from 8 to $20 \mathrm{dr}^{5}$. The tax payers are brewers and are, according to the editors, all «representatives of Taembes», who apparently lived at Talae, a village of the same toparchy 6 .

${ }^{1}$ For this kind of small format documents (symbola) written in double, often receipts, see H.J. WolfF, Das Recht der griechischen Papyri Aegyptens in der Zeit der Ptolemäer und des Prinzipats, II, München 1978, p. 75-77. The Hibeh texts fit Wolff's description: they are receipts issued by government officials and contain subscriptions both in demotic and in Greek.

2 This hole is clearly visible in $\mathbf{1 4 0}$ and $\mathbf{1 4 1}$. In $\mathbf{1 3 7}$ the lozenge-shaped hole has been filled up with papyrus, no doubt in the cartonnage, but is still visible.

${ }^{3}$ With thanks to S.P. Vleeming (Trier), who kindly looked at my transcriptions of the demotic. Figures in bold refer to $P$. Hib. I.

${ }^{4}$ For Phebichis, see M.R. FAlivene, The Herakleopolite Nome. A Catalogue of the Toponyms with Introduction and Commentary (American Studies in Papyrology, 37), Atlanta 1998, p. 241-245.

${ }^{5}$ For the logeuterion at Phebichis and its personnel, trapezites (banker) and dokimastes (money checker), see R. BOGAERT, ZPE 120 (1998), p. 183-184. In Bogaert's survey of the taxes paid to the logeuterion in AncSoc 29 (1998-1999), the beer tax is discussed on p. $120-121$.

6 Talae is mentioned in 106, [107], 139, 140 and 141. For this village, see M.R. FALIVENE, op.cit., p. 207-208. On Falivene's map Phebichis and Talae are just $7 \mathrm{~km}$ distant. 


\begin{tabular}{|c|c|c|c|c|}
\hline P.Hib. & date & bank personnel & tax payer & amount \\
\hline 140 & $\begin{array}{l}\text { yr. 2, } \\
\text { Hathyr } 16\end{array}$ & $\begin{array}{l}\text { Pason banker } \\
\text { Stotoetis } \\
\text { dokimastes }\end{array}$ & Libys (Talae) & $19 \mathrm{dr}$. \\
\hline 138 & $\begin{array}{l}\text { yr. 2, } \\
\text { Hathyr } 24\end{array}$ & $\begin{array}{l}\text { Pason banker } \\
\text { Stotoetis } \\
\text { dokimastes }\end{array}$ & Harendotes & $8 \mathrm{dr}$. \\
\hline 106 & $\begin{array}{l}\text { yr. 2, } \\
\text { Hathyr } 30\end{array}$ & $\begin{array}{l}\text { Pason banker } \\
\text { Stotoetis } \\
\text { dokimastes }\end{array}$ & $\begin{array}{l}\text { Harendotes } \\
\text { (Talae) }\end{array}$ & $20 \mathrm{dr}$. \\
\hline 107 & $\begin{array}{l}\text { yr. 3, } \\
\text { Pauni } 30\end{array}$ & $\begin{array}{l}\text { Nikolaos banker } \\
\text { [Stotoetis] } \\
\text { dokimastes }\end{array}$ & $\begin{array}{l}{[--] \text { stis }} \\
\text { (Talae) }\end{array}$ & [20 dr.?] \\
\hline 136 & $\begin{array}{l}\text { yr. 3, } \\
\text { Pachon } 13\end{array}$ & $\begin{array}{l}\text { Nikolaos banker } \\
\text { Stotoetis } \\
\text { dokimastes }\end{array}$ & $\begin{array}{l}\text { Petosiris } \\
\text { (Talae) }\end{array}$ & $\begin{array}{l}20 \text { dr. for } \\
2 \text { months }\end{array}$ \\
\hline 141 & $\begin{array}{l}\text { yr. 3, } \\
\text { Pachon } 22\end{array}$ & $\begin{array}{l}\text { Nikolaos banker } \\
\text { Stotoetis } \\
\text { dokimastes }\end{array}$ & Petosiris & 15 dr. 3 ob. \\
\hline 137 & $\begin{array}{l}\text { yr. 3, } \\
\text { Pachon } 30\end{array}$ & $\begin{array}{l}\text { Nikolaos banker } \\
\text { Stotoetis } \\
\text { dokimastes }\end{array}$ & Petosiris & $18 \mathrm{dr}$. \\
\hline $\begin{array}{l}\text { SB XII } \\
10783 \\
(139) \\
\end{array}$ & $\begin{array}{l}\text { [yr. 3, } \\
\text { Pha]ophi }\end{array}$ & $\begin{array}{l}\text { Herakleios banker } \\
\text { Nikolaos } \\
\text { dokimastes }\end{array}$ & $\begin{array}{l}\text { Petosiris } \\
\text { (Talae) }\end{array}$ & 9 dr. \\
\hline 142 & $? ?$ & $\begin{array}{l}\text { Herakleios banker } \\
\text { Nikolaos } \\
\text { dokimastes }\end{array}$ & $? ?$ & $12 \mathrm{dr}$. \\
\hline
\end{tabular}

Normally receipts should end up in the hands of the person who paid the tax, in this case the brewers. The demotic subscriptions confirm that these were not copies kept by the bank, but documents destined for the (Egyptian) tax-payers. The receipts were, however, given to four different tax-payers (Libys, Harendotes, [- -]stis and Petosiris), who apparently succeeded each other in time. In the view of the editors all four act for a certain Taembes, who lived at Talae. Taembes was therefore an important person in the beer business at Talae. As was shown by the editors of $P$. Yale I, p. 133, she was probably a tax farmer. It is remarkable, therefore, that she was a woman, as can be seen from her name, which probably means «She of (the goddess) $H n b{ }^{7}$.

${ }^{7}$ For the snake goddess $H n b$, who was mainly worshipped in the Heracleopolite nome, see M. Thirion, Notes d'onomastique, Rev. d'Eg. 37 (1986), p. 136-137 and 42 (1991), 
There is, however, a problem of reading and interpretation at this point of the texts. Grenfell and Hunt clearly indicate that instead of the expected genitive article $\tau$ o $\tilde{v}$ the papyri have only $\tau$. Considering this an abbreviation, they read it as $\tau \mathrm{o}(\tilde{\mathrm{v}})$. This is, however, most unusual in Ptolemaic papyri, and it is preferable not to correct the texts and to take $\tau$ ó as the neuter singular article ${ }^{8}$. In P. Hib. I 106 for instance we read: $\pi \varepsilon \dot{\varepsilon} \tau \tau \omega \kappa \varepsilon v$

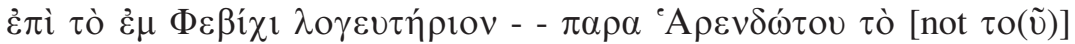

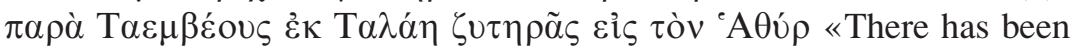
paid into the collecting office at Phebichis - - from Harendotes the (amount) due from Taembes in Talae for beer tax on account of Hathyr». By this reading Harendotes (and the other tax payers) still pay for Taembes, but they are no longer called her representatives.

All texts are followed by a one-line demotic subscription, one text (140) has in addition a line of demotic on the back. It is typical of the relationship between Greek and demotic papyrology that in no case this demotic line has been published. When Hunt and Edgar republished 106 in Select Papyri II 375, they did not even mention the presence of the demotic at the bottom. This demotic evidence is therefore presented here for the first time. It is unfortunately damaged in every single case. We think we can identify the name $T a-h n b$ on the back of 140 , but unfortunately the traces are too indistinct to be sure.

107 belonged to the collection of Leipzig, but was lost in World War II and no photographs are available 9 . According to the Oxyrhynchus checklist $\mathbf{1 3 6}$ is now in the Cairo museum, but as the inventory number is not known, it has not been possible to localise this text. In 142 the demotic line is illegible.

In the following texts the demotic has been partially preserved:

141 (Columbia University; photo available on the APIS site): this is the best preserved item and most of the others can only be read by comparison to the Columbia piece.

p. 230, D. Devauchelle, Rev. d'Eg. 51 (2000), p. 29-31, and C. LeITZ, Lexikon der ägyptischen Götter und Götterbezeichnungen, V (OLA, 114), Leuven 2002, p. 220. For the rendering of $H n b$ by $-\varepsilon \mu \beta \eta \varsigma$ in Greek, see P. Count I 491.12 note.

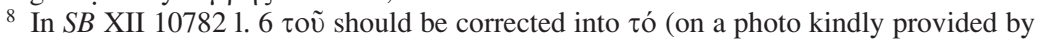
Marilyn Parca).

9 Information provided by D. Colomo. 

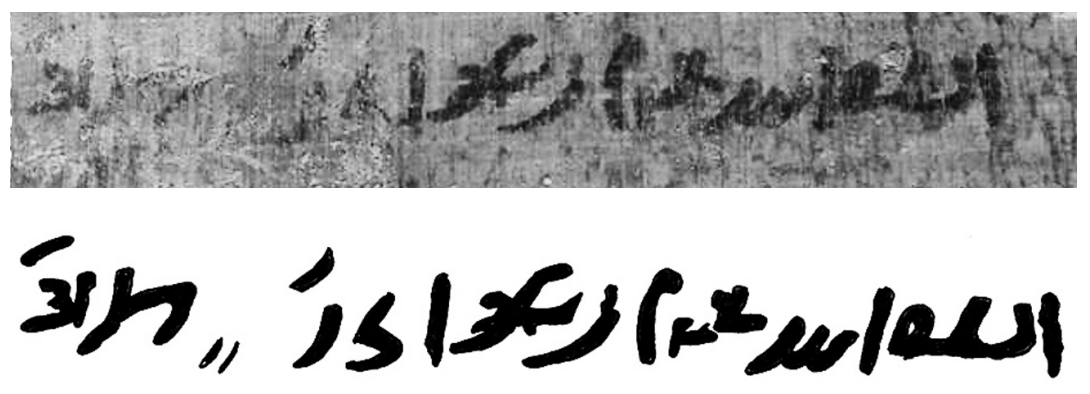

i.ir.hr P3-di-Wsir s3 Nh.t-Hr followed by an amount in kite. From the Greek one expects 7 1/2 kite 3 ob., but the figure looks rather like 3 followed by a fraction. Mark Depauw suggests 3 kite 5/6, which would be half of the expected sum.

SB XII 10783 (Chicago, McCormick Theological Seminar): the beginning of the line is less well preserved than in 141, but the text is clearly the same. The line is not broken off to the left and there are no figures either here or on the next line.
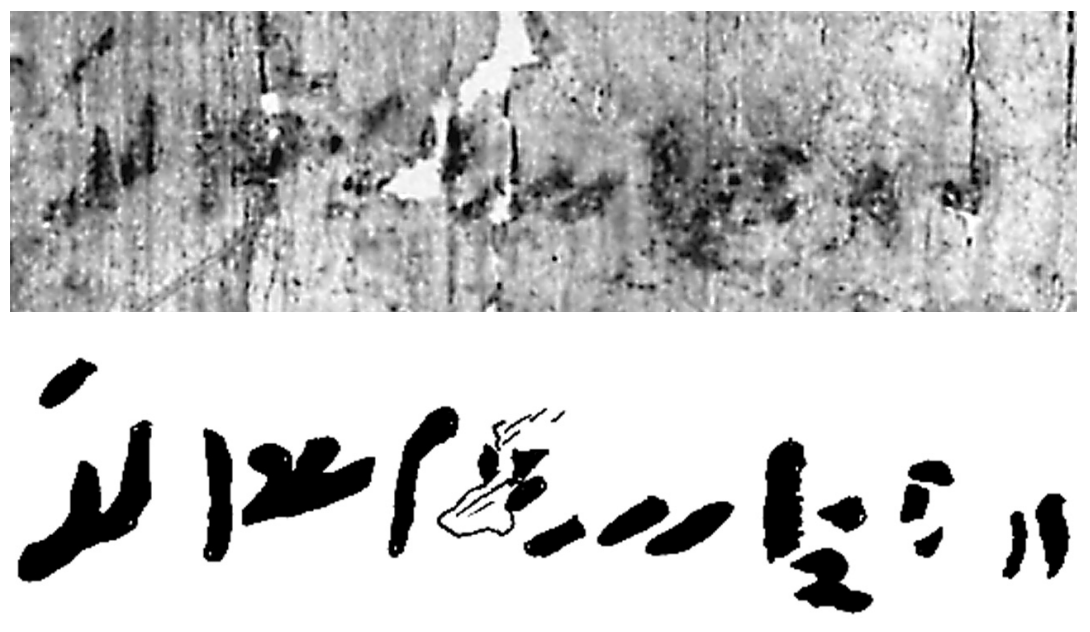

i.ir.hr P3-di- 'Wsir s3 Nhth- Hr

In 137 the last line is severely damaged and only the beginning is preserved $^{10}$. This can be deciphered only thanks to $\mathbf{1 4 1}$.

10 A photo is available on the APIS site under the APIS number p643. The papyrus has a number in red ink AM 4433 and some plaster of the cartonnage is preserved at the bottom. 

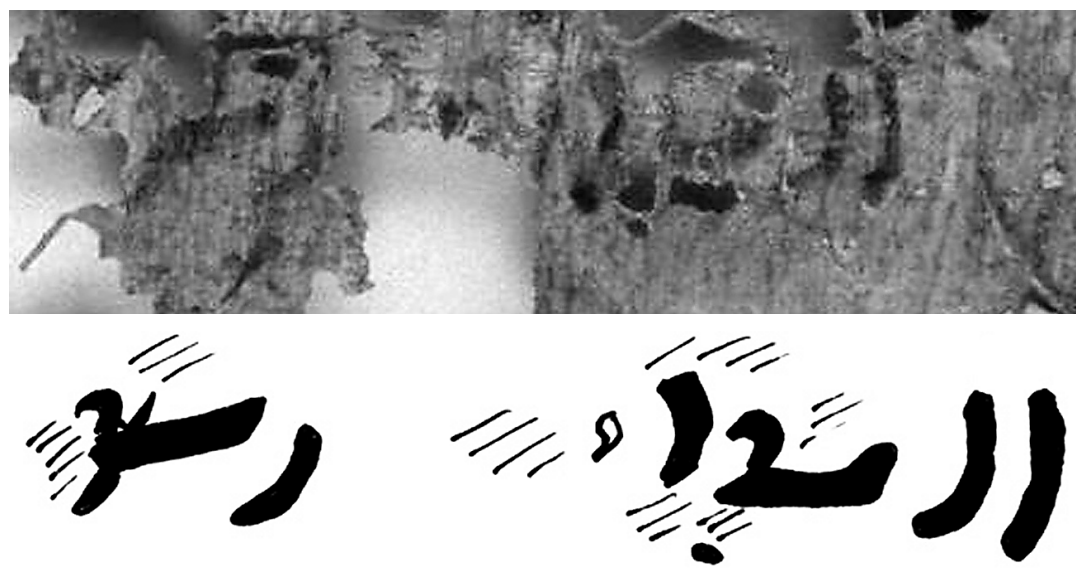

i.ir.hr [P3-di-Wsir] s3 Nht-[Hr - - -

140 (Bruxelles, MRAH E5959) presents again the same formula followed by the same name. The beginning is largely lost.

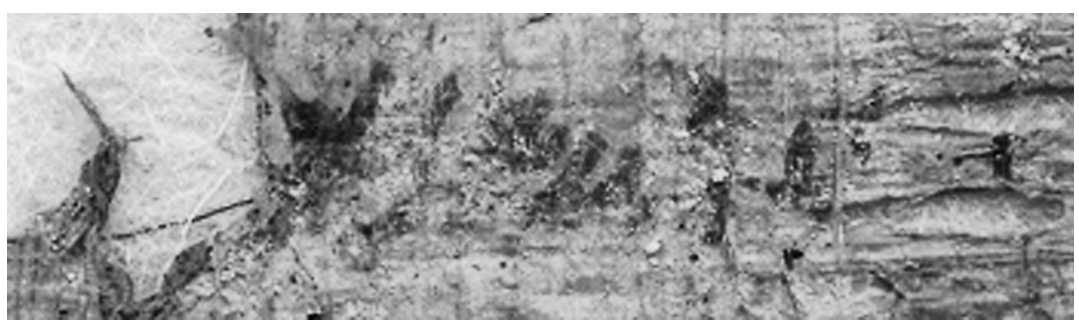

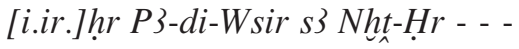

Since the Greek receipt is addressed to Libys, the appearance of Petosiris here is unexpected.

This text also has one line of demotic also on the back:

- before cleaning:

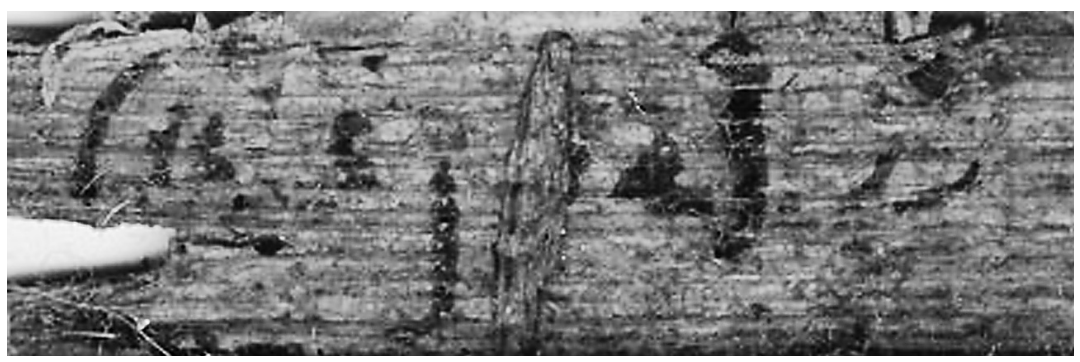


- after cleaning:
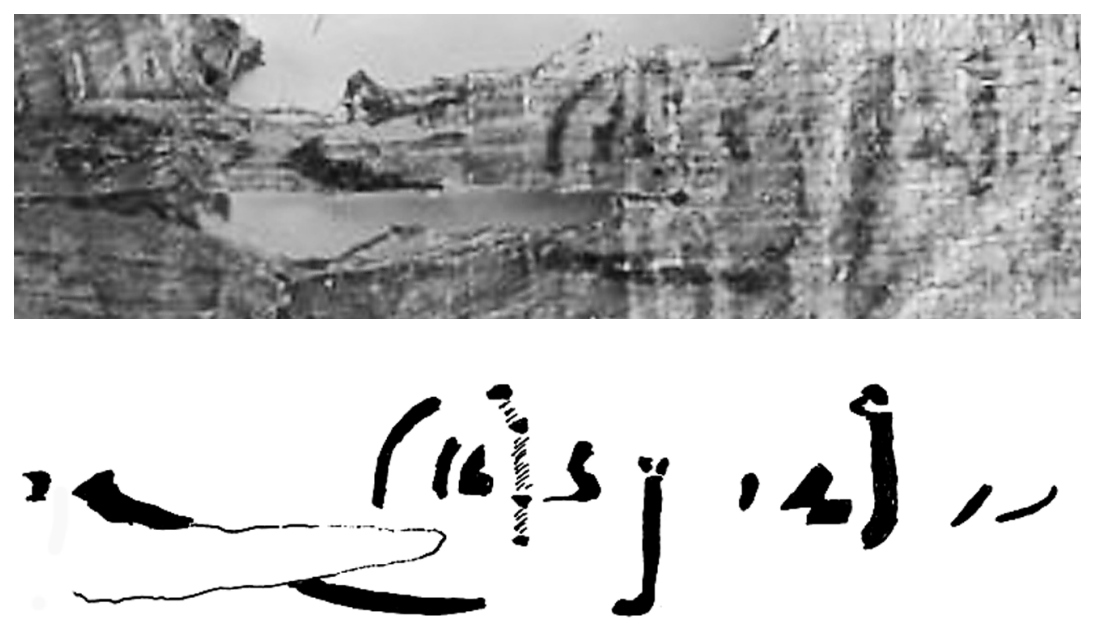

p3 hq (?) n-dr.t Ta-ḥnb 9 [1/2]

The payment (?) from Taembes 9.5 (kite)

As the first word is masculine, it cannot be the word for beer $(h q(. t))$, which is feminine. The reading of the following word is guesswork, the only certain sign being the divine determinative at the end. The reading $T a-h n b$ is just possible, when compared to the writings of that name offered by Devauchelle in Rev d'Eg. 51, p. 29 and 31. The initial $h$ is largely missing, but the few remaining traces could fit a high-rising sign; the $b$ is clear and then follows a divine determinative. The snake determinative which is usually found is not there and the reading may be wishful thinking after all. The figure 9, ending in a long flourish below, is clear and $91 / 2$ kite correspond to the 19 drachmas mentioned in the main text on the recto.

138 (Graz, Univ. Ms. I 1932): the demotic bottom line is badly preserved, but enough is visible to establish that it does not correspond to 141. It apparently starts with $i . i r-h r=$ «in front of», which should be followed by a personal name. 

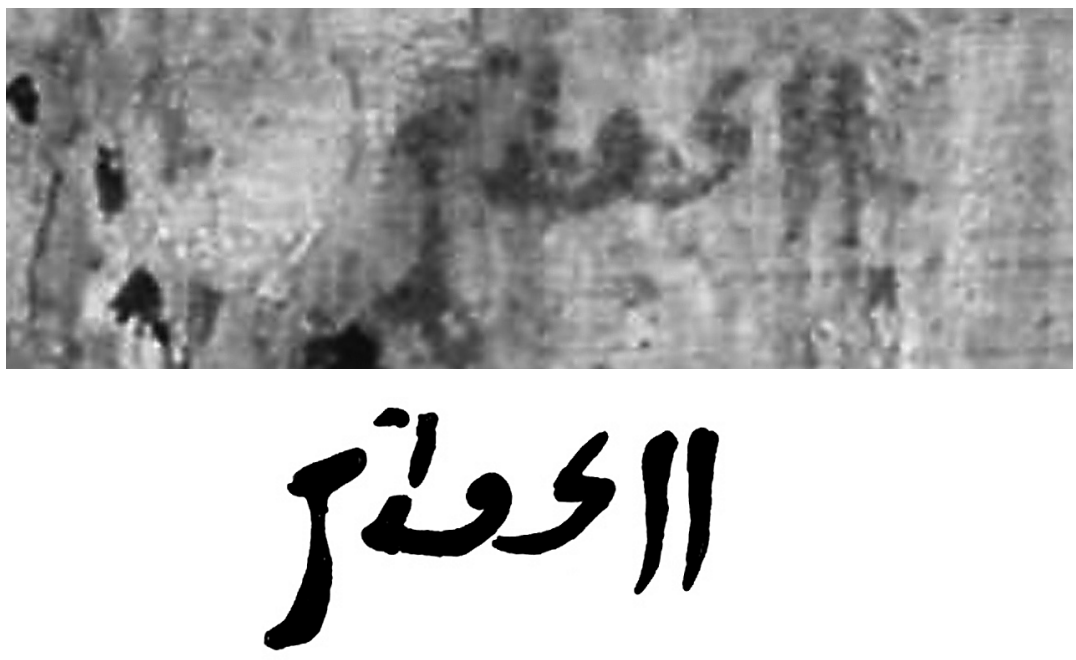

i.ir.hr..[

The new evidence from the demotic lines is limited, but intriguing. In most cases it mentions «Petosiris son of Nechtyris», probably as payer. It is tempting to identify him with the Petosiris who is mentioned in 136, 137, 139 (= SB XII 10783) and 141. But Petosiris son of Nechtyris also occurs in 140, where Libys is the payer, not Petosiris. It therefore cannot be ruled out that he is a different person.

B-3000 Leuven

Willy CLARYSSE

Onderzoekseenheid Oude Geschiedenis 